\section{Maximizing Local and National}

Assessment for Evidence-Based Librarianship

\author{
Ellysa Stern Cahoy and \\ Loanne Snavely, \\ Guest Columnists
}

Correspondence for Reference \& User Services Quarterly should be addressed to Editor Diane Zabel, Schreyer Business Library, The Pennsylvania State University, 309 Paterno Library, University Park, PA 16802; e-mail:dxz2@psu.edu.

Ellysa Stern Cahoy is Assistant Head, Library Learning Services and Loanne Snavely is Head, Library Learning Services at The Pennsylvania State University.
A few months ago I was riveted by an in-house presentation disseminating results from a 2008 survey of computing by Penn State University faculty, students, and staff. I couldn't help but think that RUSQ readers would also find the Penn State data interesting, especially comparisons with national survey data. I invited one of the presenters (Loanne Snavely) to collaborate with Ellysa Stern Cahoy on an article that would share data from this survey as well as another locally executed survey. Both of these surveys represent a library partnership with other campus units. Additionally, I asked the authors to provide advice on how other libraries can replicate what Penn State has done in this area, and to demonstrate the importance of national and local technology-focused surveys for assessment.—Editor

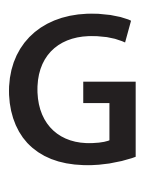

aining a perspective on student and faculty opinions and abilities relevant to libraries and information technology (IT) is integral to and can locally inform planning for future services and resources. Yet, without ready access to campuswide survey instruments, how can academic librarians assess their users in this area? Building a culture of assessment can enrich evidence-based librarianship and provide a sound basis for decision making and strategic planning. ${ }^{1}$ LibQUAL+ and other standardized library assessment tools have provided a basis for understanding library user needs, and surveys of technology use are becoming more essential to library planning. With the continued merging of libraries and IT on college campuses, it makes sense to capitalize on and integrate within already existing IT user surveys. The constant and rapid shift in popular technologies mandates that librarians, faculty, IT departments, and all of higher education understand how students and faculty are using technology in connection with library resources. This knowledge assists librarians in developing technology-related resources, programming, collections, and services, keeping library programming vital and relevant.

In only a few years, librarians have witnessed a shift from e-mail to instant messaging to Facebook, from landline telephones to cell phones to the mobile Web. What are the national technology trends, and how do they play out on an individual campus? How do technology trends inform the development of new services and experimentation with emerging methods for serving users? This article provides strategies for using national surveys of library users and leveraging and maximizing partnerships for local library data collection and analysis. The Penn State University Libraries have locally executed two surveys of faculty and students in partnership with Penn State Information Technology Services 


\section{FROM THE EDITOR}

and the Office of Student Affairs, Research and Assessment. Details of the Penn State studies are shared in this article, along with examples of national technology surveys useful in local benchmarking.

\section{NATIONAL TECHNOLOGY-FOCUSED SURVEYS}

In recent years, the academic library community has used LibQUAL+, a primary assessment tool, to manage user satisfaction with and effectiveness of library services. ${ }^{2}$ Based on SERVQUAL, a survey instrument designed to measure service quality for businesses, LibQUAL+ was developed by the Association of Research Libraries in collaboration with Texas A\&M faculty. ${ }^{3}$ Designed to identify gaps in library services, LibQUAL+ provides libraries with a standardized, Web-based survey to help librarians objectively evaluate services. ${ }^{4}$ The tool also carries the option of benchmarking results with other peer institutions (and LibQUAL+ participants). LibQUAL+ covers a broad range of library topics of interest, including information literacy outcomes, effectiveness of services, and library as place. Responses can be broken down by specific audiences, including discipline, age, sex, and academic status. While it is a highly powerful survey tool, it is one that is administered solely by the library without buy-in from other campus groups. Furthermore, LibQUAL+ may not provide the in-depth technology and library-use data needed to develop new and cutting edge services in today's library environment.

Findings from national, technology-focused surveys can provide a powerful foundation for the structure and focus of locally based surveys. Consider the power of a statistic that can show not only your library users' abilities or views, but also a comparison with national findings. Finding that a majority of your users access the library website gains greater significance if your users turn to the library webpage at a higher rate than users nationally. There are several large, recurring national studies of technology use that can be used to help provide a baseline of comparison between students at your college or university and students nationally. Perhaps the best current supplier of student technology and libraryuse statistics is the Online Computer Library Center (OCLC), which has produced what the company refers to as "landscape reports" since 2003..$^{5}$ As its first effort in this realm, OCLC published The 2003 OCLC Environmental Scan: Pattern Recognition. ${ }^{6}$ This initial report sought to identify and detail current issues and future trends projected to affect libraries significantly. The report was focused to assist OCLC decision makers and the larger audience of librarians in strategic planning. ${ }^{7}$ Following up on the success of the Environmental Scan, OCLC produced Perceptions of Libraries and Information Resources in 2005. In the report's introduction it was noted that

there are no major recent empirical studies that look specifically and broadly at the role libraries and librarians play in the infosphere, from the point-of-view of the information consumer. How are libraries perceived by today's information consumer? Do libraries still matter? On what level? Will library use likely increase or decrease in the future? ${ }^{8}$

The 2005 report explored the library brand—specifically, how users perceived this brand and the value of libraries in general. OCLC partnered with the corporate research firm Harris Interactive to survey library users in six countries: Australia, Canada, India, Singapore, the United Kingdom and the United States. Users were asked their relationship with, awareness of, and trust of library resources and services. The report provided an important, never-before-seen snapshot of the brand effect of libraries in the day-to-day lives of information consumers. The following are sample questions from Perceptions of Libraries and Information Services:

- How much has your personal library use changed over the last three to five years?

- Please indicate if you have used the following electronic information sources, even if you have used them only once. (The list of choices included search engine, library website, online databases, and online library question service.)

- Where do you typically begin your search for information on a particular topic??

In 2006, OCLC published College Students' Perceptions of Libraries and Information Resources, a subset of the 2005 report that focuses on a specific audience. Containing invaluable data for academic libraries, this report shares data on students' general use and familiarity with libraries, usage of libraries (in-person and online), perceptions of the library brand, and student advice for libraries and librarians. Specifically, the report covers the responses of 396 college students, both graduate and undergraduate, from the 2005 report. Responses from fourteen- to seventeen-year-olds are also in the report to provide contrast with current college students and context on needs of potential future college students. Because it is a subset of the 2005 report, the same questions are used, but college student response trends and patterns are highlighted. In the introduction to the report, Cathy DeRosa, OCLC vice president for marketing and library services, writes, "As is the case with the full Perceptions report, the findings presented in this report do not surprise, they confirm." ${ }^{10}$ The report highlights the significance of drawing out the responses from a specific population to gain different insights into certain user group needs.

OCLC took a different approach to their research in 2007 with the publication of Sharing, Privacy and Trust in our Networked World. This report looks only at a core set of issues facing libraries-the use of social spaces online and expectations for libraries in this realm. It explores user behaviors and preferences in online social spaces (including Facebook and MySpace), user attitudes toward sharing information online (including library websites and social spaces), user attitudes 
toward online privacy, and librarian views of social spaces and future possibilities for library services in this realm. This study expands to include users in Germany, France, and Japan. U.S. library directors were also queried as part of the study. The following are representative questions included in the study:

- What type(s) of online activities have you done or participated in during the last twelve months?

- Generally, do you think that your personal information on the Internet is kept more private than, less private than, or the same as it was two years ago?

- How likely would you be to participate in each of the following activities on a social networking or community site if built by your library? Choices included being notified of terms of interest to you, sharing ideas with library staff about services, and self-publishing creative work. ${ }^{11}$

The Pew Internet and American Life Project has also been a source of statistical reports relevant to libraries. Known as a nonpartisan, "non-profit 'fact tank,"'12 the project regularly shares data findings on the effect of the different aspects of the Internet on a variety of audiences, including adolescents and adults. The Pew project primarily conducts phone surveys and relies on information from research partners. Recent Pew reports include Information Searches that Solve Problems: How People Use the Internet, Libraries and Government Agencies When They Need Help and Teens and Social Media. ${ }^{13}$ Each report surveys a large number (from more than nine hundred to several thousand) of U.S. residents on a specific topic related to the Web. While these surveys are not directly library related, they can provide data that highlights how users are responding to and integrating specific aspects of the Web into their daily lives.

Ithaka's 2006 Studies of Key Stakeholders in the Digital Transformation in Higher Education also yields powerful data for libraries. The project details the aggregated responses from more than four thousand faculty, indicating preferences and opinions on the role of the library in higher education, the future of the library as a repository, faculty publishing, and the library as scholarly publisher. Libraries interested in their faculty's feedback would be wise to build questions related to the Ithaka study and compare responses accordingly. ${ }^{14}$

\section{ASSESSMENT PARTNERING ON LOCALLY BASED SURVEYS}

Saunders points out that LibQUAL+ contains a "tension between the need for local information and the standardized information provided by the survey."15 Indeed, surveys like LibQUAL+, while powerful and highly standardized, may not conform to the needs of a specific campus or library environment. It is to a library's advantage to gain a more locally relevant picture of student perceptions and needs. Optimally, a local survey could be designed to easily correlate with national findings.
In two instances in recent years, the Penn State Libraries found that partnering with others has enabled a better understanding of student and faculty use of library resources. Through partnerships with Information Technology Services (ITS) and the Office of Student Affairs Research and Assessment, the Libraries have been able to take the pulse of our students in a survey devoted exclusively to library topics and in another survey in which the Libraries' questions were integrated with technology questions. One incentive to survey students was to clarify how our students were doing with regard to library use and acquisition of information literacy. Recent national surveys indicated that people in general, and students in particular, were not using libraries and library resources as much as they had in the past; in fact, they were using them at a very low rate. These reports created significant discussions about the future of libraries. But, in examining the results, it seemed that there was considerable ambiguity in at least some of the questions. Were the surveys asking the questions so the responder knew what they meant? Were the results a reflection of an actual problem? While the Libraries could not answer the questions on the scale of the national survey, we could ask questions our own way and discover to what extent students were using our webpages, databases, and online resources. Penn State ITS has a history of surveying students and faculty with regard to campus IT issues and trends. Two surveys in particular-the Penn State Pulse surveys and the Faculty Advisory Committee on Academic Computing (FACAC) survey of Penn State faculty and students-have yielded powerful longitudinal data comparisons for nineteen Penn State campuses and provided an opportunity to ask library-focused questions.

\section{THE PENN STATE PULSE SURVEYS}

The Pulse surveys began at Penn State in 1995 as a method for acquiring student feedback, usage trends, views, and behaviors. As of May 2008, 156 Pulse surveys have been administered to Penn State students by the Office of Student Affairs, Research and Assessment. The surveys are conducted by phone or online, and a typical survey draws several thousand valid responses from students across Penn State's nineteen campuses. In 2005, a Pulse survey on information literacy was conducted in partnership with the Penn State Libraries, garnering 2,003 responses from undergraduate students. ${ }^{16}$ The survey focused on students' knowledge of the Libraries' services, collections, and resources, as well as on their information-seeking behaviors. Questions were developed by two librarians (the head of Library Learning Services and the head of Public Services), the senior director of Teaching and Learning with Technology, and the head of the assessment team from the Office of Student Affairs, Research and Assessment. The team allowed the librarians to create the direction and content for the questions, which was done in consultation with other librarians. Rough questions and areas were then discussed as a group to look for things such as broad understanding and clarity of question content 


\section{FROM THE EDITOR}

and wording. The advice provided through this consultative process was invaluable and resulted in questions that were asked differently than we librarians might have asked them but were clear enough to elicit the information desired from responding students.

The results of the survey highlighted Penn State students' self-reported achievement of information literacy competencies (88 percent felt confident in their ability to find and retrieve information, 73 percent were familiar with library guides and databases, and 81 percent felt able to find needed library resources), research competencies (88 percent indicated the ability to assess the validity and authority of Web information), use of specific library resources, and exposure to a library course-related instructor (over 70 percent reported having a librarian as a guest lecturer in class).

\section{THE FACAC SURVEY}

In place since 2001, Penn State's FACAC survey of technology use has targeted a variety of different campus technology users-students, TAs, faculty, and staff. The survey has grown to a response pool of nearly three thousand users. When the FACAC survey began, the focus was entirely on technologyrelated questions, including the use of computers, adequacy of campus technical support, and preferred methods of technology training. Since then, the terrain covered by the survey has grown to include the use of electronic and mobile devices, frequency of specific Web-based activities, use of technology in teaching, and active participation in the social Web.

In 2007, the Penn State Libraries had the unique opportunity to contribute questions for the FACAC survey. While the FACAC survey questions are a tightly controlled groupas they represent the needs of many ITS units on campus-a number of library-related questions were included in the final version. The Libraries felt this collaborative survey was especially important because so much of what students do is aggregated under the general heading of "technology," and nearly everything students do to seek and find informationand to ultimately integrate it into papers and projects - is done through and with the use of technology. It made sense, and we felt sure it would make sense to students, to have library and IT questions seamlessly included in one survey. The Libraries contributed a variety of questions to the survey, nearly all of which were used. ${ }^{17}$ In an effort to draw upon and compare responses with national statistics, specific questions were designed to correlate with OCLC survey questions. This enabled later direct comparison with the national OCLC findings.

The following are a few of the questions contributed by the libraries to the 2008 FACAC survey:

- Please indicate if, in the last year, you have used any of the following online resources and services.

My Library Account

The CAT (Online library catalog)

Library databases (ProQuest, Lexis, etc.)

Online Reference Materials
Google Scholar

Electronic Books

Electronic magazines and/or journals

ASK! Online library help service

- During the last year, how often did you access the Libraries webpage?

- How frequently do you require your students to use online library resources? (faculty only)

\section{FACAC SURVEY FINDINGS: COMPARISON WITH NATIONAL SURVEY DATA}

The library questions included in the 2008 FACAC survey presented thought-provoking results when compared with the results of College Students' Perceptions of Libraries and Information Resources. While the FACAC survey's response pool of 1,771 undergraduate students and 231 graduate students was much larger than the OCLC pool of 396 student responses, conclusions could still be drawn. Looking at the two studies together yields some positive information regarding Penn State students' information literacy skills. In particular, major library research and discovery tools (the online catalog and library databases) were used at a dramatically higher rate. Worldwide, 38 percent of college students used the library catalog at least once annually, while 79 percent of Penn State students used the library catalog (the CAT) at least once last year. Worldwide, 33 percent of college students reported using library databases at least once. At Penn State, 64 percent of students used databases at least yearly. Worldwide, 61 percent of college students used a library website annually, while nearly 75 percent of Penn State students used the Libraries' website at least yearly. Use of e-journals by Penn State students is lower; 40 percent compared with almost 60 percent of students worldwide. It was hypothesized that the current labeling in use on the Libraries' website affected this statistic. While some libraries call their list of databases "e-journals," the Libraries most frequently use the terms "databases," "resources," and "articles" on their webpages. Another question on the FACAC survey addressing a specific local concept may also assist in explaining the lower response to the e-journal question. The Libraries' "Get it @ PSU” button appears in many databases and in Google Scholar, which leads students to full-text articles in other licensed databases. Half of Penn State students report using this feature to get "full-text journal articles," a phrase that may be more familiar to them. Use of ebooks is nearly equivalent between the two groups: just over 30 percent of college students worldwide and 28 percent of Penn State students. Use of ASK! (the Libraries' help service) was higher locally: 14 percent of Penn State students compared to only 8 percent of college students nationally. ${ }^{18}$

\section{USING FACAC SURVEY RESULTS FOR PLANNING AND IMPROVEMENT}

The planning of new service initiatives, including the Libraries' future Knowledge Commons, has been affected by the 
findings of these surveys. The FACAC survey reported that 88 percent of students on campus owned laptop computers. This impressive statistic helped reinforce the importance of robust wireless access and a multitude of power outlets throughout the libraries, and the creation of more laptop-centered areas in the Knowledge Commons to encourage students to bring their laptops to campus by providing comfortable and convenient places to use them. Nearly half (46 percent) of undergraduate students self-reported that instructors have required a multimedia project as a class assignment during this academic year. Based upon this and other anecdotal evidence, the Libraries began planning in collaboration with ITS for a multimedia creation suite to be housed in the libraries.

Social networking made a significant showing, with 83 percent of students, 34 percent of faculty, and 23 percent of staff having Facebook accounts. This information encourages us to continue development on our existing Facebook library applications and to consider developing new ones. In questions asking for likelihood of participation, more than 50 percent of students indicated they would "post your favorite library materials on your Facebook profile," confirming that students not only use Facebook but would use it for desirable library applications. Since this is not one of the current features available in the Penn State Libraries Facebook application, it gives direction for the Libraries' next project. In ranking their preferences for ways to get help, "getting help in person" was given the highest rating by 55 percent of students, with e-mail as the next most preferred, encouraging us to retain these two services even as we expand our other forms of virtual reference service. Even though students communicate in a wide variety of ways, 84 percent still used e-mail daily while 26 percent updated their Facebook and MySpace accounts daily. Nearly all (93 percent) did online research and searches, and 83 percent used online resources, such as Wikipedia. One-fourth of the students reported having taken at least one online course in the past year. Another result-that 42 percent of students accessed library materials through ANGEL, our course management system (CMS) indicates the success of our custom-designed CMS library tools: electronic reserves, custom library guides, and our ASK! virtual reference service (which includes IM, chat, e-mail, and phone options).

YouTube and similar video-sharing sites were used by 77 percent of students, 58 percent of faculty, and 46 percent of staff to view multimedia content-this statistic helps the Libraries consider how the delivery of instructional resources and point-of-use assistance can be enhanced by brief videos. Nearly all students (95 percent) owned a cell phone (as well as 85 percent for faculty and staff) and 78 percent owned an iPod or another MP3 player (as well as 55 percent of faculty and 41 percent of staff), indicating the increasing use of mobile handheld devices. Students used their cell phones for multiple purposes, including calling (88 percent); text messaging (74 percent); taking, sending, and viewing photos (55 percent); receiving bulletins or alerts from automated services (27 percent); playing games ( 25 percent); viewing videos (18 percent); listening to music (17 percent); accessing the Web (14 percent); and sending e-mail (11 percent). This shows that students and faculty might be very receptive to finding and receiving information through their preferred handheld device if the library can deliver it in a convenient form. Indeed, it may also indicate that if we do not respond to this booming trend, academic users might look elsewhere. Thus a focus on developing interfaces and resources that can be used or are adaptable for use with a handheld device may be highly rewarded if successfully implemented.

For some time, declining library use has gained national press, yet Penn State Libraries' traffic and use of resources continues to grow. Even book circulation, which has declined slightly over several years, is still relatively high. Despite a high degree of student laptop ownership, computer usage in our libraries as well as in labs across campus is high, with students often having to wait for a computer. One survey finding may help explain this use pattern: The FACAC survey asked faculty for the frequency with which they required students to use the library during a semester, and nearly 70 percent reported at least once (which included 18 percent who responded "constantly throughout the semester" and 21 percent who responded "3 or more times").

Some faculty data can assist us in understanding faculty preferences. A total of 88 percent had DSL or cable modem connections at home. Most faculty (80 percent) used technology classrooms, 31 percent had connected their personal laptop to the podium when teaching a class, about one-third used YouTube for teaching purposes, 13 percent reported using Google applications such as Google Docs, and 6 percent reported using simulations or educational games in their teaching. Their preferred methods for communicating with students were e-mail (92 percent) and ANGEL ( 86 percent), while other forms of communication were extremely low: discussion lists ( 8 percent), instant messaging (4 percent), blogs ( 3 percent), wikis ( 2 percent), text messaging (2 percent), and Facebook and MySpace (2 percent). A total of 29 percent rated their skill in teaching with technology as "advanced," and 48 percent rated their skills as "intermediate." While only 7 percent taught exclusively online, 57 percent reported that they had taught a hybrid or blended course. Most (91 percent) had used the CAT in the past year, 78 percent report using databases, and 74 percent report using their My Library Account-their online account for items borrowed, renewals, etc. Online reference resources were used by 59 percent and Google Scholar by 56 percent of faculty. The ASK! service had been used by 21 percent of faculty, but 59 percent reported that their most preferred method of receiving help from the Libraries was by e-mail. Most (85 percent) reported that they were somewhat or very likely to receive notification of library materials of interest to them, while 57 percent reported that they were likely or very likely to share ideas with Libraries' faculty and staff about services, and 49 percent would receive library recommendations from friends. These survey results can assist librarians in their liaison activities with classroom faculty 


\section{FROM THE EDITOR}

through an enhanced understanding of their preferences and technology use.

\section{STRATEGIES FOR PARTNERING AT YOUR INSTITUTION}

Local surveys, coordinated with several national survey questions and conducted in partnership with other units, have worked well at Penn State, and we believe this strategy can be effective for other libraries as well. We would encourage other academic libraries to extend their assessment data and knowledge about their users by partnering with other units on campus that gather such data. With the national trend in higher education and with the encouragement of accrediting agencies such as the Middle States Commission on Higher Education, assessment is becoming increasingly important and is consequently receiving more attention, thought, and committed resources. Many institutions have an office of planning and assessment with a staff devoted to tracking various institutional measures. At a more granular level, many departments and units have their own positions devoted to assessment. Here are some strategies to apply when attempting to partner on a data gathering project:

- Do your homework: Ferret out the offices and individuals responsible for assessment on your campus and explore what they do and how they do it. They can often be wonderful allies in gathering campuswide information. Our experience with two units, the Office of Student Affairs, Research and Assessment, and Teaching and Learning with Technologies (a unit of ITS), has demonstrated the outstanding success such partnerships can produce.

- Determine what information you really want: Will it be helpful to compare to national data? If so, locate the data and use parallel questions. Set your goals.

- Be proactive: You aren't likely to get a knock on your door asking you to participate in a survey or assessment project. Make appointments with the appropriate people. Talk about your need for information in the context of what they do. Don't expect them to do something outside their scope or mission. Emphasize the usefulness of the data for all parties and for overall institutional assessment.

- Plan ahead: Advanced planning and patience is essential. In the case of the Penn State Pulse survey, more than eighteen months was required for planning, gathering input on possible questions, developing the actual questions, and getting in the queue to have the survey administered. Receiving the results and data analysis added several more months. For the FACAC survey, the library was one of many groups wishing to add some questions to the survey, which threatened to become unreasonably long. Through a continued strong partnership with the group and the support of the director, most of the library questions remained in the final survey, emphasizing the importance of establishing and maintaining long-term positive relationships across campus.
- Develop your assessment tool: Work with experts to design clear, unambiguous questions. Avoid library jargon. Read up on developing good survey questions. Listen to the advice of your partners. They are assessment experts.

- Present the results: When finished, invite your partners to present the results to your library faculty and staff. If the survey was not exclusively related to the library, have them present their results as well.

- Improve!: Use the results to improve your performance, implement new services, and inform your strategic directions.

\section{CONCLUSION}

For both of the local surveys, the Penn State Libraries were able to use the assessment expertise of others on campus to create high-quality instruments that were administered broadly to large, random samples of students, and have the statistical analysis completed. This enabled the Libraries to do far more than we could have if attempting the surveys alone. A subsequent survey on the effectiveness of the Libraries' Facebook application also included similar questions from the FACAC and OCLC studies, continuing the pattern of analyzing local and national comparisons. The more often questions are repeated over time and in different survey tools, the more longitudinal the data becomes, and richer comparison opportunities are created. These powerful comparisons enable the Libraries to readily see not only service strengths and frequently used resources, but how Penn State students differ from students nationally in their use of online library resources. The findings allow the Libraries to plan future online services more effectively, with an eye toward the specific needs of Penn State students and faculty. As a result of these surveys, the Libraries are also more able to respond to emerging trends by comparing our own student data to national surveys. We can be proud that Penn State students report using our most essential library resources, the library catalog and library databases, at a dramatically higher rate than reported by college students nationally. This assures us that, while we may not ever feel we are doing enough in the classroom to reach all of our students, our programming (which is targeted first at novice users and second at the disciplinary level) is having a significant effect on our student body. While we would love to find that 100 percent of our students are using our resources regularly and effectively, comparison with national data helps us measure our success within a broader perspective.

Additional data on our local student and faculty populations is also informing our planning and future directions, helping us to implement positive change that will enhance our users' experience with the library and use of library resources. As funding gets tighter and new initiatives and continued funding are increasingly tied to data and strategic plans, gathering data and using it for evidence-based library decisions is not only wise but essential. What you discover may help keep your library at the heart of your institution. 


\section{References}

1. Douglas J. Joubert and Tamera P. Lee, "Empowering Your Institution Through Assessment," Journal of the Medical Library Association 95, no. 1 (2007): 46-53.

2. E. Stewart Saunders, "The LibQUAL+ Phenomenon: Who Judges Quality?" Reference E User Services Quarterly 47, no. 1 (Fall 2007): $21-24$.

3. Ibid.

4. Fred Heath et al., "Emerging Tools for Evaluating Digital Library Services: Conceptual Adaptations of LibQUAL+ and CAPM," Journal of Digital Information 4, no. 2 (2004), http://journals.tdl.org/ jodi/article/viewArticle/jodi-115/101 (accessed Dec. 5, 2008).

5. OCLC, Sharing, Privacy and Trust in Our Networked World, www .oclc.org/reports/sharing/default.htm (accessed Dec. 5, 2008).

6. OCLC, Environmental Scan: Pattern Recognition, www.oclc.org/ reports/escan (accessed Dec. 5, 2008).

7. Ibid.; OCLC, College Students' Perceptions: Libraries \& Information Resources, www.oclc.org/reports/perceptionscollege.htm (accessed Dec. 5, 2008).

8. OCLC, Perceptions of Libraries and Information Resources, www.oclc .org/reports/2005perceptions.htm (accessed Dec. 5, 2008).

9. Ibid.

10. OCLC, College Students' Perceptions.

11. OCLC, Sharing, Privacy and Trust in Our Networked World.

12. Pew Internet and American Life Project, About Us, www.pewinternet .org/about_mission.asp (accessed Jan. 29, 2009).
13. Lee Estabrook, Evans Witt, and Lee Rainie, Information Searches that Solve Problems: How People Use the Internet, Libraries, and Government Agencies When They Need Help (Pew Internet \& American Life Project, 2007), www.pewinternet.org/pdfs/Pew_UI_ LibrariesReport.pdf (accessed Dec. 5, 2008); Amanda Lenhart et al., Teens and Social Media (Pew Internet \& American Life Project, 2007), www.pewinternet.org/pdfs/PIP_Teens_Social_Media_Final .pdf (accessed Dec. 5, 2008).

14. Ross Housewright and Roger Schonfeld, Ithaka's 2006 Studies of Key Stakeholders in the Digital Transformation in Higher Education (Ithaka Project, 2008), http://www.ithaka.org/publications/ facultyandlibrariansurveys (accessed Dec. 5, 2008).

15. Saunders, "The LibQUAL+ Phenomenon," 24.

16. Penn State Division of Student Affairs, How Do You Know: Information Literacy (State College, Pa.: Penn State Univ., 2005), www sa.psu.edu/SARA/pulse/137-InformationLiteracy.pdf (accessed Dec. 5, 2008).

17. Brian Sonak and Vicki S. Williams, Survey of Technology Use at Penn State by Faculty, Staff, and Students, http://tlt.its.psu.edu/about/ reports/2008/2008-Technology-Use.pdf/view (accessed Dec. 5, 2008).

18. Ellysa Stern Cahoy, "OCLC Comparisons-E-Tech," www .personal.psu.edu/esc10/blogs/E-Tech/2008/08/facac-oclc -comparisons.html (accessed Dec. 4, 2008); Sonak and Williams, Survey of Technology Use. 